\title{
Studi Eksperimen Proses Tempering Terhadap Kekerasan Permukaan dan Estimasi Keausan
}

\author{
Windra Sampurna, Yusuf Kaelani \\ Jurusan Teknik Mesin, Fakultas Teknologi Industri, Institut Teknologi Sepuluh Nopember Surabaya \\ (ITS) \\ Jl. Arief Rahman Hakim, Surabaya 60111 Indonesia \\ e-mail: y_kaelani@me.its.ac.id
}

\begin{abstract}
Abstrak-Akhir-akhir ini banyak beredar berbagai macam produk suku cadang pin piston mulai dari produk original yang biasanya berharga mahal, hingga produk-produk non original yang harganya relatif lebih murah.saat ini produk non original yang dijual dipasaran, harganya setengah kali lebih murah dibandingkan dari harga produk original. Sehingga perlu membandingkan kualitas dari sifat-sifat mekanis antara pin piston original dengan non original. Langkah-langkah penelitian yang dilakukan adalah melakukan proses heat treatment pada spesimen pin piston non original dibawah titik lebur $850^{\circ} \mathrm{C}$ dan ditahan selama 30 menit, kemudian di-quenching dengan media air setelah itu dilanjutkan dengan proses tempering pada suhu $200^{\circ} \mathrm{C}, 400^{\circ} \mathrm{C}$ dan $600^{\circ} \mathrm{C}$ dengan waktu penahanan 60 menit. Hasil pengujian kekerasan didapatkan bahwa nilai rata-rata kekerasan dengan metode Rockwel pada spesimen yang tidak diberikan perlakuan panas pada suhu ruang $28^{\circ} \mathrm{C}$ yaitu sebesar 55 HRC untuk spesimen pin piston original dan 54 HRC untuk spesimen pin piston non original setelah melewati tahap proses heat treatment dan proses quenching, pin piston non original memiliki kenaikan masing-masing sebesar 7,4 \%, 1,85\% dan penurunan sebesar $11,11 \%$ pada setiap proses tempering $200^{\circ} \mathrm{C}, 4^{\circ}{ }^{\circ} \mathrm{C}$ dan $600^{\circ} \mathrm{C}$. Spesimen pin piston non original dengan proses tempering $200^{\circ} \mathrm{C}$ adalah spesimen yang nilai kekerasannya mendekati spesimen pin piston original. Dengan peningkatan kekerasan sebesar $5,45 \%$ dibandingkan dengan spesimen original.
\end{abstract}

Kata Kunci-heat treatment, pin piston, tempering

\section{PENDAHULUAN}

AMAN sekarang, produk sepeda motor berkembang pesat. Data kepolisian pada tahun 2013 jumlah sepeda motor di Indonesia berjumlah 84.732 .652 (www.bps.go.id). Jumlah tersebut akan terus meningkat seiring dengan kebutuhan transportasi masyarakat. Agar kinerja mesin motor terjaga, tentunya harus dilakukan servis rutin dan jaminan ketersediaan suku cadang kendaraan. Salah satu suku cadang kendaraan yang dilakukan pergantian adalah pin piston. Pin piston merupakan komponen mesin yang berfungsi sebagai pemindah gaya dalam hubungan antara connecting rod dengan bushing piston.

Pin piston biasanya terbuat dari baja karbon sedang AISI 4140 merupakan low alloy chromium-molybdenum steels yang memiliki kandungan $0,38-0,43 \% \mathrm{C}, 0,75-1,00 \% \mathrm{Mn}, 0,15-$ $0,30 \% \mathrm{Si}, 0,80-1,10 \% \mathrm{Cr}, 0,15-0,25 \% \mathrm{Mo}, 0,04 \% \mathrm{~S}$ dan $0,035 \%$ P. Berdasarkan aplikasinya baja ini dikembangkan dengan tujuan untuk memiliki sifat mekanik terutama kekerasan, kekuatan serta tahan terhadap keausan. Keausan bahan yang lebih lunak. Faktor-faktor yang mempengaruhi keausan adalah kecepatan, tekanan, kekasaran permukaan dan kekerasan bahan.

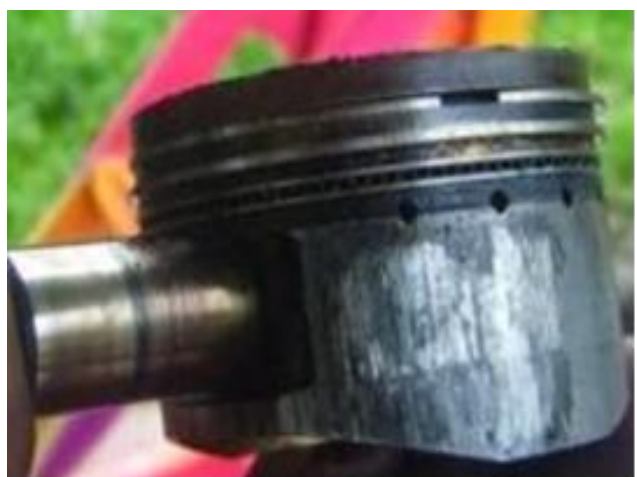

Gambar 1. Kerusakan pin piston

Pin piston tersebut terjadi pengikisan atau aus pada permukaan yang disebabkan karena pin yang digunakan tersebut tidak mempunyai kekerasan yang cukup. Kekerasan akan meningkat apabila material dilakukan proses heat treatment, semakin tinggi angka kekerasan maka sifat keuletan akan menjadi rendah dan laju keausan juga akan menurun.

\section{METODOLOGI}

Penelitian ini dilakukan melalui beberapa langkah kerja sebagai studi eksperimental. Awalnya dengan melakukan persiapan spesimen, yaitu membeli produk pin piston original dan non original. Kemudian melakukan pengujian kekerasan permukaan terhadap masing-masing spesimen uji. Penelitian kekerasan dilakukan dengan menggunakan metode Rockwell C. Pada pengujian kekerasan dengan metode Rockwell C, digunakan pembebanan $150 \mathrm{Kgf}$ dengan waktu penahanan 60 detik dan menggunakan intan sudut $120^{\circ}$. Setelah dilakukan pengujian kekerasan permukaan pin pada masing-masing spesimen uji. Spesimen non original akan dilakukan proses heat treatment dibawah titik lebur pada temperatur $850^{\circ} \mathrm{C}$ dengan waktu penahanan selama 30 menit. Kemudian di dinginkan cepat atau quenching dengan media air. Kemudian, spesimen uji akan dilakukan proses tempering dengan variasi temperatur $200^{\circ} \mathrm{C}, 400^{\circ} \mathrm{C}$ dan $600^{\circ} \mathrm{C}$. Adapun alat yang digunakan dalam penelitian ini dapat dilihat pada Gambar 2. 


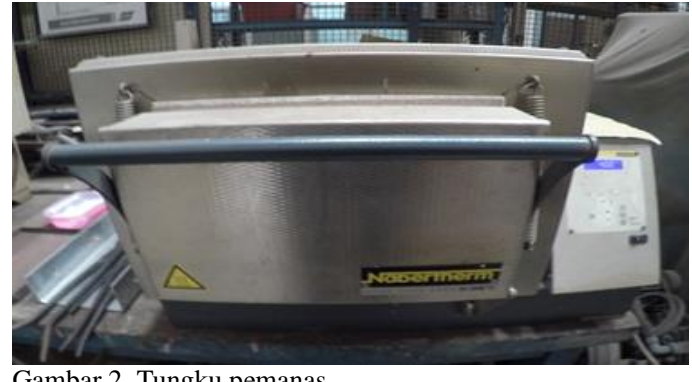

Gambar 2. Tungku pemanas

Setelah melewati proses heat treatment dan proses tempering. Spesimen uji pin piston non original akan dilakukan pengujian kekerasan. Pengujian ini dilakukan untuk mengetahui apakah proses tempering tersebut mempengaruhi niai kekerasan dan proses tempering mana nilai kekerasannya lebih mendekati dengan spesimen uji lain. Alat yang digunakan dalam pengujian kekerasan dapat dilihat pada Gambar 3.

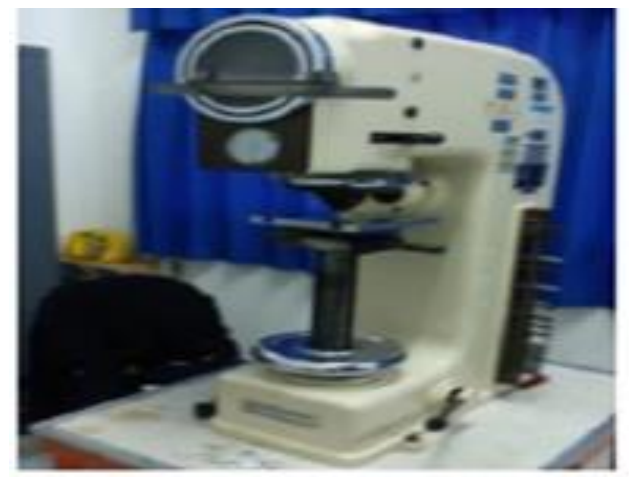

Gambar 3. Rockwell hardness tester

\section{HASIL DAN PEMBAHASAN}

Pada bagian ini akan dibahas dan dianalisa hasil eksperimen proses tempering dan kekerasan pin piston sepeda motor.

\section{A. Analisa Proses tempering $200^{\circ} \mathrm{C}$}

Pada proses dengan suhu tempering $200^{\circ} \mathrm{C}$ dengan waktu penahanan atau holding time selama 60 menit dapat dilihat pada Gambar 4.

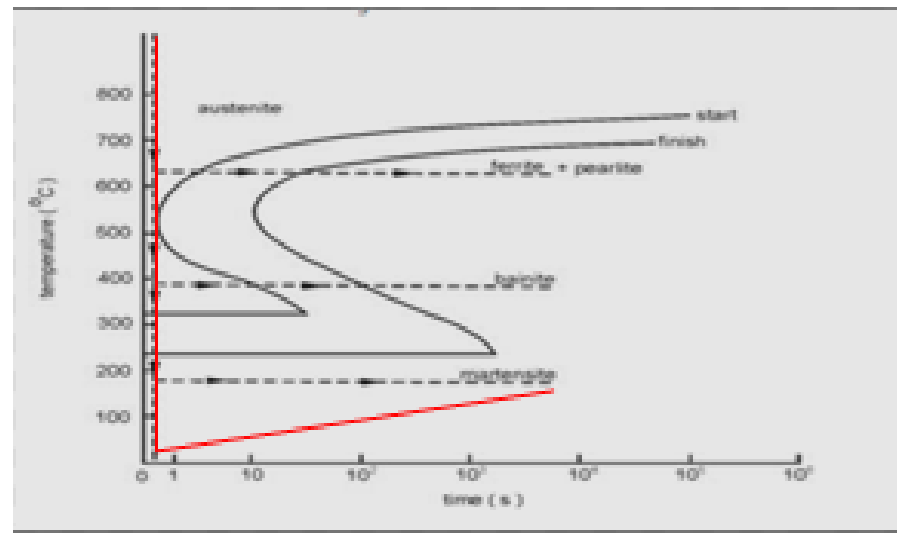

Gambar 4. Proses tempering $200^{\circ} \mathrm{C}$

Diagram prosses tempering yang ditunjukkan pada Gambar 4 dengan asumsi garis berwarna merah adalah struktur yang terjadi setelah dilakukan proses tempering $200^{\circ} \mathrm{C}$. Pada proses ini struktur yang terjadi yaitu martensit yang bersifat keras dan rapuh berpartisipasi menjadi martensit temper, pada proses ini struktur perlit lebih mendominasi dibandingkan struktur ferit.

\section{B. Analisa Proses tempering $400^{\circ} \mathrm{C}$}

Pada proses dengan suhu tempering $400^{\circ} \mathrm{C}$ dengan waktu penahanan atau holding time selama 60 menit dapat dilihat pada Gambar 5

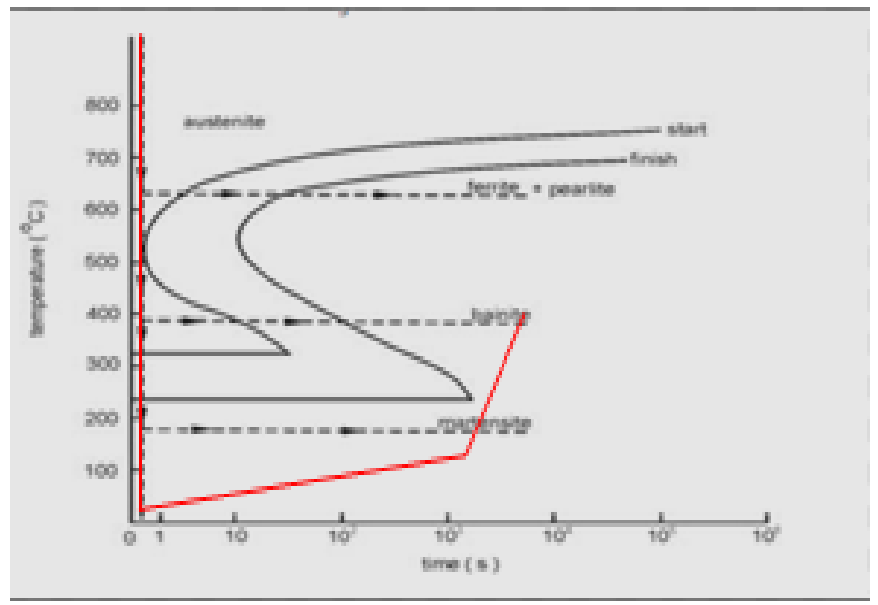

Gambar 5. Proses tempering $400^{\circ} \mathrm{C}$

Diagram proses tempering yang ditunjukkan pada Gambar 5 dengan asumsi garis berwarna merah adalah struktur yang terjadi setelah dilakukan proses tempering $400^{\circ} \mathrm{C}$. Pada proses ini struktur yang terjadi yaitu ferit dan perit lebih merata. Sedangkan martensit berkurang sedikit dibandingkan proses tempering $200^{\circ} \mathrm{C}$

\section{Analisa Proses tempering $600^{\circ} \mathrm{C}$}

Pada proses dengan suhu tempering $600^{\circ} \mathrm{C}$ dengan waktu penahanan atau holding time selama 60 menit dapat dilihat pada Gambar 6.

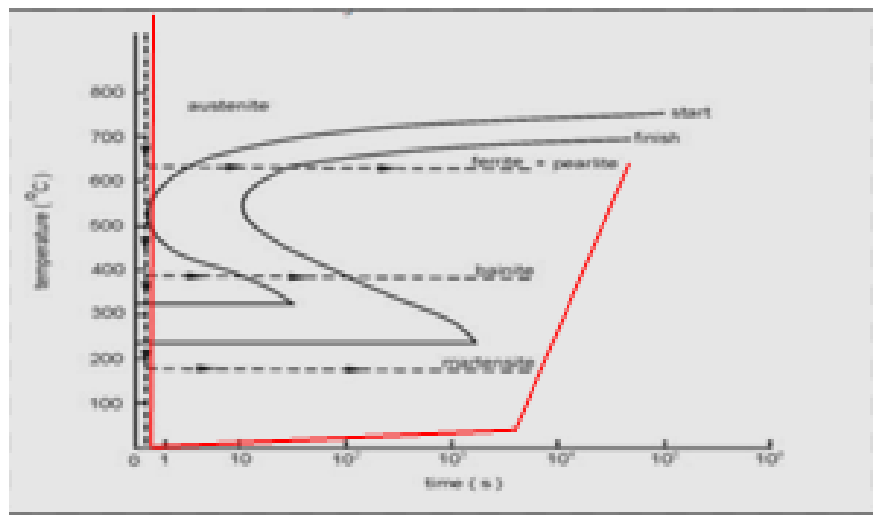

Gambar 6. Proses tempering $200^{\circ} \mathrm{C}$

Diagram prosses tempering yang ditunjukkan pada Gambar 6 dengan asumsi garis berwarna merah adalah struktur yang terjadi setelah dilakukan proses tempering $600^{\circ} \mathrm{C}$. Pada proses ini struktur yang terjadi yaitu ferit dan perit lebih merata dan mendominasi. Sedangkan martensit lebih sedikit dibandingkan proses tempering $200^{\circ} \mathrm{C}$ dikarenakan suhu pemanasan yang lebih tinggi. 


\section{Pengujian kekerasan rockwell pada permukaan spesimen}

Pengujian kekerasan permukaan pada spesimen diambil kekerasannya dibeberapa titik yang sudah ditentukan. Tiap spesimen diambil lima titik pengujian, dapat dilihat pada Gambar 7.

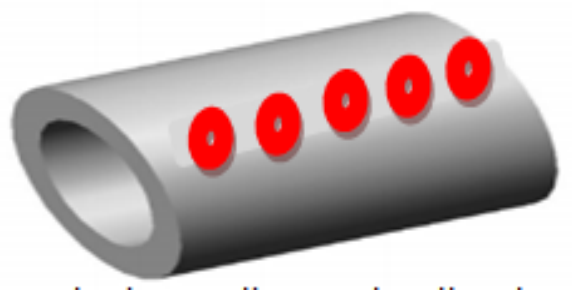

Gambar 7 Titik pengujian Rockwell pada permukaan spesimen

E. Data hasil pengujian kekerasan Rockwell pada permukaan dan data hasil komposisi kimia.

Pada pengujian kekerasan dengan metode Rockwell C, digunakan pembebanan $150 \mathrm{Kgf}$ dengan waktu penahanan 60 detik dan menggunakan intan sudut $120^{\circ}$ untuk spesimen pin piston original maupun pin piston non original. Hasil percobaan dapat dilihat pada Tabel 1 dan Tabel 2.

Tabel 1.

Data hasil pengujian komposisi kimia pada spesimen uji

\begin{tabular}{ccc}
\hline \hline \multirow{2}{*}{ Unsur } & \multicolumn{1}{c}{$\%$} & \\
& Non original & Original \\
\hline $\mathrm{Fe}$ & 97,1 & 97,2 \\
$\mathrm{C}$ & 0,409 & 0,443 \\
$\mathrm{Cr}$ & 0,933 & 0,958 \\
$\mathrm{Mn}$ & 0,734 & 0,771 \\
$\mathrm{Si}$ & 0,195 & 0,203 \\
$\mathrm{Mo}$ & 0,180 & 0,185 \\
\hline \hline
\end{tabular}

Tabel 2.

Data hasil pengujian kekerasan permukaan pada spesimen pin piston original

\begin{tabular}{|c|c|c|c|c|c|}
\hline \multirow{3}{*}{$\begin{array}{c}\text { Spesimen } \\
\text { Original } \\
\left(28^{\circ} \mathrm{C}\right)\end{array}$} & \multicolumn{5}{|c|}{ Teknik Pengujian } \\
\hline & 1 & 2 & 3 & 4 & 5 \\
\hline & 55 & 55 & 55 & 55 & 54 \\
\hline \multicolumn{6}{|l|}{ Rerata } \\
\hline HRC Pin & & & 55 & & \\
\hline \multicolumn{6}{|l|}{ Original } \\
\hline Non & 1 & 2 & 3 & 4 & 5 \\
\hline $\begin{array}{c}\text { Original } \\
\left(28^{\circ} \mathrm{C}\right)\end{array}$ & 53 & 54 & 54 & 54 & 54 \\
\hline \multicolumn{6}{|l|}{ Rerata } \\
\hline HRC Pin & & & 54 & & \\
\hline \multicolumn{6}{|l|}{ Original } \\
\hline Non & 1 & 2 & 3 & 4 & 5 \\
\hline $\begin{array}{c}\text { Original } \\
\left(200^{\circ} \mathrm{C}\right)\end{array}$ & 58 & 57 & 58 & 58 & 58 \\
\hline \multicolumn{6}{|l|}{ Rerata } \\
\hline HRC Pin & & & 58 & & \\
\hline \multicolumn{6}{|l|}{ Original } \\
\hline Non & 1 & 2 & 3 & 4 & 5 \\
\hline $\begin{array}{l}\text { Original } \\
\left(400^{\circ} \mathrm{C}\right)\end{array}$ & 54 & 55 & 55 & 55 & 54 \\
\hline \multicolumn{6}{|l|}{ Rerata } \\
\hline HRC Pin & & & 55 & & \\
\hline \multicolumn{6}{|l|}{ Original } \\
\hline Non & 1 & 2 & 3 & 4 & 5 \\
\hline $\begin{array}{l}\text { Original } \\
\left(600^{\circ} \mathrm{C}\right)\end{array}$ & 47 & 48 & 48 & 47 & 48 \\
\hline Rerata & & & & & \\
\hline HRC Pin & & & 48 & & \\
\hline Original & & & & & \\
\hline
\end{tabular}

Hasil dari pengujian komposisi kimia pada masing-masing spesimen uji yang ditunjukkan pada Tabel 1 dimana setiap unsur pada spesimen uji pin piston original memiliki persentase lebih tinggi dibandingkan spesimen uji pin piston non original. Dengan adanya perbedaan persentase unsur kimia pada spesimen uji tersebur dapat diketahui perbedaan kekerasan permukaan antara spesimen uji pin piston original dan non original. Hal ini dapt dilihat pada Tabel 2 mengenai perbedaan kekerasan antara pin piston original dengan pin piston non original. Pengaruh perbedaan unsur kimia terhadap nilai kekerasan dapat dilihat pada Gambar 8.

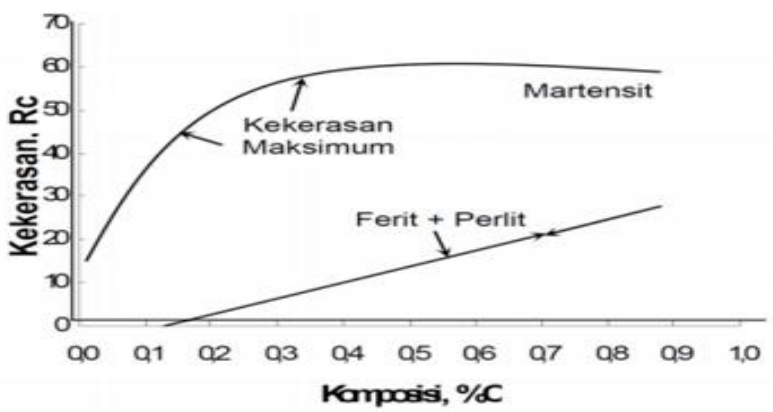

Gambar 8 Pengaruh komposisi kimia terhadap nilai kekerasan [1]

Grafik rerata kekerasan permukaan dari setiap spesimen original dan non original dengan variasi tempering $200^{\circ} \mathrm{C}$, $400^{\circ} \mathrm{C}$ serta $600^{\circ} \mathrm{C}$ dapat dilihat pada Gambar 9 .

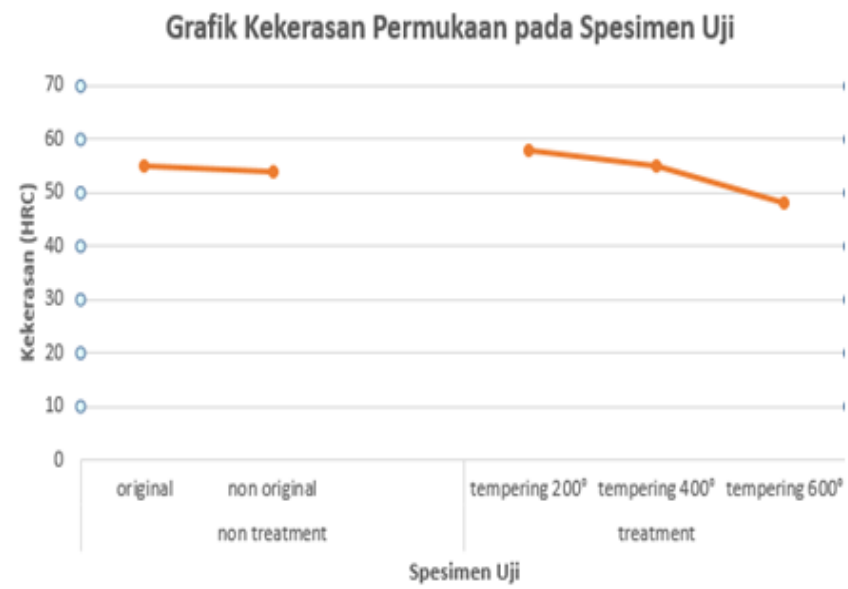

Gambar 9 Grafik pengaruh variasi tempering terhadap kekerasan permukaan spesimen uji.

Pada Gambar 9 dapat dilihat bahwa nilai kekerasan pada semua pin piston non original yang sudah dilakukan proses heat treatment telah terjadi peningkatan kekerasan dan penurunan kekerasan. Spesimen pin piston non original dengan variasi tempering $200^{\circ} \mathrm{C}$ nilai kekerasannya meningkat $7,4 \%$ dari spesimen pin piston non original dengan rerata kekerasan 58 HRC. Pada spesimen dengan variasi tempering $400^{\circ} \mathrm{C}$ nilai kekerasannya meningkat $1,85 \%$ dari spesimen pin piston non original dengan rerata kekerasan 55 HRC. Spesimen dengan variasi tempering $600^{\circ} \mathrm{C}$ memiliki penurunan $11,11 \%$ dari spesimen pin piston non original dengan rerata kekerasan 48 HRC. Penurunan kekerasan akibat proses tempering disebabkan struktur martensit cenderung untuk berubah menjadi martensit temper dan cenderung bertransformasi menjadi bainit atau endapan karbida. Jadi dapat dikatan bahwa menurunnya kekerasan bahan disebabkan oleh menurunnya 
sifat tetragonal martensit dan mulai terbentuknya pengendapan karbida dan pembentukan ferit dengan meningkatnya temperatur temper.

Berdasarkan hasil pengujian kekerasan pada pesimen pin piston dengan menggunnakan metode Rockwell dapat disimpulkan bahwa spesimen non original dengan proses tempering $200^{\circ} \mathrm{C}$ terjadi peningkatan kekerasan paling tinggi yaitu sebesar $7,4 \%$ dari spesimen non original yang tanpa diberikan proses heat treatment dan terjadi peningkatan sebesar $5,4 \%$ dibandingkan dengan spesimen original. Peningkatan kekerasan tersebut terjadi disebabkan pada saat pendinginan melalui range austenite metastabil, proses nukleasasi berjalan lambat. Pada saat proses nukleasasi berjalan lambat, dilakukan pendinginan cepat sehingga inti akan tumbuh perlahan yang disebabkan proses difusi, jarak inti atom menuju batas butir memerlukan jarak dan waktu yang lebih lama sehingga butir austenite menjadi lebih besar dan kasar sehingga hardenability spesimen menjadi meningkat. Dari pengujian yang dilakukan pada spesimen non original, proses tempering $200^{\circ} \mathrm{C}$ memiliki hasil yang paling sesuai.

\section{KESIMPULAN}

Kesimpulan yang dapat diambil dari penelitian yang telah dilakukan adalah sebagai berikut:

1. Nilai rerata kekerasan Rockwell spesimen pin piston yang tidak mengalami proses perlakuan panas pada suhu ruang $28^{\circ} \mathrm{C}$ yaitu sebesar $55 \mathrm{HRC}$ untuk spesimen pin piston original dan 54 HRC untuk spesimen pin piston non original. Setelah dilakukan proses tempering $200^{\circ} \mathrm{C}$ pada spesimen pin piston non original dengan waktu penahanan 60 menit, nilai kekerasannya meningkat $7,4 \%$ yaitu menjadi 58 HRC. Nilai ini merupakan nilai kekerasan tertinggi dibandingkan silai kekerasan spesimen pin piston non original lainnya. Terjadi penurunan sebesar $11,11 \%$ pada spesimen pin piston non original dengan proses tempering $600^{\circ} \mathrm{C}$ dengan waktu penahanan selama 60 menit. Nilai kekerasannya yaitu sebesar 48 HRC.

2. Proses tempering $200^{\circ} \mathrm{C}$ memiliki peningkatan kekerasan sebesar 5,4\% dibandigkan spesimen original

3. Proses perlakuan panas dan holding time pada spesien pin piston non original pada saat dilakukan proses tempering sangat berpengaruh terhadap kekerasan.

\section{DAFTAR PUSTAKA}

[1] Pollack, H.W, 1988,"Materials Science and Metallurgy", $4^{\text {th }}$, New Jesey, Prentice Hall 